GRASAS Y ACEITES 69 (3)

July-September 2018, e266

ISSN-L: 0017-3495

https://doi.org/10.3989/gya.0230181

\title{
Antioxidant and anticancer efficacy of therapeutic bioactive compounds from fermented olive waste
}

\author{
A.E. Mahmoud ${ }^{\mathrm{a}}$, S.A. Fathy ${ }^{\mathrm{b}}$, M.M. Ali ${ }^{\mathrm{a}, \bigotimes}$, M.K. Ezz ${ }^{\mathrm{b}}$ and A.T. Mohammed ${ }^{\mathrm{a}}$ \\ ${ }^{a}$ Biochemistry Department, Genetic Engineering and Biotechnology Research Division, \\ National Research Centre, Dokki 12622, Giza, Egypt \\ ${ }^{b}$ Biochemistry Department, Faculty of Science, Ain Shams University, Cairo, Egypt \\ ${ }^{\square}$ Corresponding author: mmali1999@yahoo.com
}

Submitted: 25 February 2018; Accepted: 07 May 2018

SUMMARY: Olive pomace, which is considered as one of the worst agro-industrial wastes in Mediterranean countries was tested for bioactive compounds production through the solid state fermentation of Kluyveromyces marxianus. Because they present potent biological activities, phenolic compounds from both unfermented and fermented pomace were extracted with simultaneous evaluation of their antioxidant and anticancer activities. Conditions for optimum total phenolic recovery with maximum antioxidant activity were optimized using methanol as the extracting solvent with a sample to solvent ratio of $1: 10$ at $50{ }^{\circ} \mathrm{C}$ for 2 hours. The in-vitro anticancer activity of both extracts was assessed against different human cancer cell lines. The results revealed that both extracts exerted anticancer effects close to the value of doxorubicin drug against liver HepG2 and breast MCF-7 cell lines, and moderate activity against prostate PC 3 and colon HCT116 cell lines. Nevertheless, the fermented extract was more potent than the unfermented one. No effect against lung A549, cervix Hela cancer cell lines or normal HFB4 cells was observed for both extracts. A GC/MS analysis was carried out to determine the compounds responsible for antioxidant and anticancer activities. The results showed the presence of methyl palmitate, methyl oleate, and ethyl oleate in the methanolic extract of unfermented olive pomace, while that of the fermented one showed the production of carvacrol, thymol, eugenol, caryophyllene oxide and methyl isopalmitate.

KEY WORDS: Anticancer; Antioxidant; Bioactive compounds; Fermentation; Olive pomace

RESUMEN: Eficacia antioxidante y anticancerígena de compuestos bioactivos terapéuticos de residuos de la fermentación de aceitunas. El orujo de oliva considerado como uno de los peores residuos agroindustriales en los países mediterráneos fue ensayado para la producción de compuestos bioactivos mediante fermentación en estado sólido de Kluyveromyces marxianus. Se extrajeron los compuestos fenólicos de orujos fermentados y no fermentados ambos con potentes actividades biológicas y se evaluaron sus actividades antioxidantes y anticancerígenas. Se optimizaron las condiciones para la recuperación fenólica óptima con actividad antioxidante máxima, estas se lograron usando metanol como disolvente de extracción con una relación de muestra a disolvente de $1: 10$ a $50{ }^{\circ} \mathrm{C}$ durante 2 horas. La actividad anticancerígena in vitro de ambos extractos se evaluó frente a diferentes líneas celulares de cáncer humano. Los resultados revelaron que ambos extractos ejercen un efecto anticancerígeno cercano al valor del fármaco doxorrubicina contra líneas celulares hepáticas HepG2 y MCF-7 de mama, y actividad moderada contra líneas celulares de PC3 de próstata y HCT116 de colon, sin embargo, el extracto fermentado fue más potente que el no fermentado. No se observó ningún efecto contra las líneas celulares A549 de cáncer el pulmón, de cuello de útero o células HFB4 normales, para ambos extractos. El análisis GC/MS se llevó a cabo para determinar los compuestos responsables de las actividades antioxidantes y anticancerígenas. Los resultados mostraron la presencia de palmitato de metilo, oleato de metilo y oleato de etilo en el extracto metanólico de orujo de oliva no fermentado, mientras que el fermentado mostró la producción de carvacrol, timol, eugenol, óxido de cariofileno e isopalmitato de metilo.

PALABRAS CLAVE: Anticancerígeno; Antioxidante; Compuestos bioactivos; Fermentación; Orujo de oliva

ORCID ID: Mahmoud AE https://orcid.org/0000-0002-4335-4824, Fathy SA https://orcid.org/0000-0001-7543-7205, Ali MM https://orcid.org/0000-0002-4931-4153, Ezz MK https://orcid.org/0000-0001-6805-1013, Mohammed AT https://orcid.org/0000-0002-6122-7247

Citation/Cómo citar este artículo: Mahmoud AE, Fathy SA, Ali MM, Ezz MK, Mohammed AT. 2018. Antioxidant and anticancer efficacy of therapeutic bioactive compounds from fermented olive waste. Grasas Aceites 69 (3), e266. https://doi.org/10.3989/gya.0230181

Copyright: (C2018 CSIC. This is an open-access article distributed under the terms of the Creative Commons Attribution 4.0 International (CC BY 4.0) License. 


\section{INTRODUCTION}

Phenolic compounds represent one of the main classes of bioactive compounds which play an important role in cancer prevention and treatment primarily due to their antioxidant, anticarcinogenic and antimutagenic effects. Dietary polyphenols have received tremendous attention among nutritionists, food scientists and consumers due to their potent antioxidant properties and their marked effects in the prevention of various oxidative-stress-associated diseases. Research aiming to find fruits, vegetables, plants, agricultural and agro-industrial residues as sources of bioactive compounds has been intensified (Dai and Mumper, 2010).

The olive oil industry represents a major seasonal industry in Mediterranean countries with an important economic role. However, it is associated with the production of a vast amount $(2,880,500$ tonnes/year) of a solid environmentally polluting residue known as olive oil cake or olive pomace (OP) (Nunes et al., 2016). The disposal of this waste is a challenging task for olive oil producing countries due to its unfavorable physico-chemical characteristics (Nunes et al., 2016). Nevertheless, OP is one of the most important agro- industrial sources of phenolic compounds since only $2 \%$ of the polyphenols contained in the olive fruit are transferred into olive oil while the other $98 \%$ remain in olive oil byproducts (about $45 \%$ of the total phenolics in the olive fruit is retained in OP) (Ciriminna et al., 2016). To date, only a few papers in the literature have focused on the evaluation of the phenolic content of $\mathrm{OP}$ as a potential source of bioactive compounds for pharmaceutical and food industries. Thus, it is of great interest to recover an extract enriched with phenolic compounds, from the low-cost, environmentally polluting and widely available by-product, OP (Aliakbarian et al., 2011).

Solid State Fermentation (SSF) can be used successfully for the extraction/production of bioactive compounds on industrial scale for use in food, feed, chemical applications and for the treatment of diseases. In addition, the substitution of synthetic substrates by agro-industrial residues is considered a valuable approach that does not only eliminate the environmental pollution caused by these wastes, but also allows for their valorization (Mahmoud et al., 2009; Mahmoud and Ali, 2012).

Scarce research in the literature has focused on the in vitro cytotoxic activity of OP phenolic extracts against different cell lines including HepG2 human hepatoma cell line (Ranchal et al., 2014) and MDA-MB-231 breast cancer cell line (Ramos et al., 2013).

Moreover, a polyphenol extract from OP was proven to restore anoxia-impaired endothelial functions through the regulation of genes expression more efficiently than the single purified components owing to synergism. Therefore, the combined use of polyphenols, as in OP extract, could represent a powerful tool for the treatment and chemoprevention of diseases.

This study aimed to recover an extract enriched with phenolic compounds from the environmental polluting agro-industrial waste, OP, through an ecofriendly technique, SSF, which involves the fermentation of the generally-recognized-as-safe (GRAS) yeast, Kluyveromyces marxianus NRRL Y-8281. The optimal conditions for phenolic compound extraction from unfermented (UFOP) and fermented OP (FOP) were studied. The effect of fermentation on the phenolic content and antioxidant activity of OP was assessed. In addition, the individual components of UFOP and FOP methanolic extracts were identified using the GC/MS technique. Finally, the in vitro anticancer activity of UFOP and FOP methanolic extracts was evaluated against different cell lines.

\section{MATERIALS AND METHODS}

\section{1. MATERIALS}

\subsubsection{Olive pomace waste}

The olive pomace (OP) generated from a threephase decanter system was provided by a local olive-pressing factory located in Al-Arish, North Sinai, Sinai Peninsula, Egypt, during olive harvesting season. The OP was stored till used in a deep freezer at $-20{ }^{\circ} \mathrm{C}$.

\subsubsection{Microorganism}

Kluyveromyces marxianus NRRL Y - 8281 yeast was purchased from Agricultural Research Service (Peoria, Illinois, USA).

\subsubsection{Cell lines and culturing}

The anticancer impact of the unfermented and fermented extracts was evaluated on HepG2 (liver), MCF-7 (breast), A549 (lung), Hela (cervix), PC3 (prostate), HCT116 (colon) and HFB4 (normal human melanocyte) cell lines purchased from ATCCT (Rockville, MD, USA). Maintenance of the cells was achieved as previously described by El Malah et al., (2016).

\subsection{METHODS OF ANALYSIS}

\subsubsection{Culture conditions}

Adaptation of yeast was conducted according to Wickerham (1951). The strain was streaked onto a YME/agar medium and then incubated for $48 \mathrm{~h}$ at $30{ }^{\circ} \mathrm{C}$. Every 4 weeks the stock was sub-cultured and 
stored at $4{ }^{\circ} \mathrm{C}$. The inoculum preparation was done by inoculating a loop of the culture in a sterile inoculum medium $(50 \mathrm{ml})$ of the same composition of the stock medium without agar. The inoculum was then incubated under shaking conditions $(150 \mathrm{rpm}$, for $24 \mathrm{~h}$ at $30^{\circ} \mathrm{C}$ ).

\subsubsection{Solid state fermentation}

Inoculum of $1 \mathrm{ml}$ (containing about $10^{8}$ cells $\left./ \mathrm{ml}\right)$ was inoculated into $5 \mathrm{~g}$ of sterilized OP (sterilized at $121{ }^{\circ} \mathrm{C}$ for $20 \mathrm{~min}$ at $15 \mathrm{psi}$ ) in Erlenmeyer flasks $(250 \mathrm{ml})$. The Inoculated flasks were incubated statically for $48 \mathrm{~h}$ at $45^{\circ} \mathrm{C}$ (Mahmoud et al., 2018).

\subsubsection{Polyphenol extraction}

Both unfermented olive pomace (UFOP) and fermented olive pomace (FOP) were dried in an oven at $50{ }^{\circ} \mathrm{C}$. The dried extracts were ground by an electrical blender to get powder. The resulting powder was sieved and then stored at $-20{ }^{\circ} \mathrm{C}$ until use (Mahmoud and Ali, 2012). Phenolic compounds were extracted as reported by Mahmoud and Ali (2012). One gram of dry UFOP or FOP was added to $10 \mathrm{ml}$ of solvent and incubated in a shaking water bath at $100 \mathrm{rpm}, 50{ }^{\circ} \mathrm{C}$ for $2 \mathrm{~h}$. After extraction, the extracts were filtered and the resulting filtrates were evaporated. The extracted residues were then re-dissolved in the corresponding solvent to get a concentration of $4 \mathrm{mg} / \mathrm{ml}$. The antioxidant activity and phenolic content of the reconstituted extracts were evaluated.

\subsubsection{Optimization of polyphenol extraction}

Various physico-chemical parameters influencing total phenolic recovery were optimized. The influence of solvent type (methanol, ethanol, distilled water, n-propanol, isopropanol, ethyl acetate, acetone, chloroform and hexane), sample to solvent ratio $(1: 5,1: 10,1: 15$ and $1: 20)$, extraction time (30 min, $1 \mathrm{~h}, 2,4$ and $6 \mathrm{~h}$ ) and extraction temperature $\left(30,40,50,60\right.$ and $\left.70^{\circ} \mathrm{C}\right)$ on phenolic content recovery was evaluated. The optimization of various process parameters was to estimate the influence of each individual parameter (extraction solvent, sample to solvent ratio, extraction time and extraction temperature) regardless of the others, and subsequently the optimal condition was incorporated into the experiment for optimizing the next parameter.

\subsubsection{Total phenolic assay}

The extract's total phenolic content was assessed as mentioned by Quettier-Deleu et al., (2000) as gallic acid equivalent / g dry substrate ( $\left.\mathrm{mg}_{\mathrm{GAE}} / \mathrm{gds}\right)$

\subsubsection{Antioxidant activity}

DPPH Radical-scavenging assay. The activity of the extract to scavenge the DPPH radical was evaluated by the method of Mensor et al., (2001).

$\boldsymbol{\beta}$-Carotene-linoleic acid assay. Antioxidant activity was evaluated as reported by Juntachote and Berghofer (2005).

\subsubsection{Gas chromatographic-mass spectrometric (GC/MS) analysis of UFOP and FOP methanolic extracts}

About $5 \mu$ of UFOP and FOP extracts were used. The analysis was performed using Thermo Scientific trace GC Ultra Couple with single quadrupole $\mathrm{MS}$ and a fused silica capillary column TG-5MS $(30 \mathrm{~m} \times 0.251 \mathrm{~mm}, 0.1 \mathrm{~mm}$ film thickness). The oven temperature was maintained initially at $40{ }^{\circ} \mathrm{C}$ for 3 minutes and then programmed from 40 to $280{ }^{\circ} \mathrm{C}$ with rate of $4{ }^{\circ} \mathrm{C} / \mathrm{min}$. Helium was used as carrier gas, at $1 \mathrm{ml} / \mathrm{min}$ flow rate. The determination of all the identified compounds was made using a percent relative peak area. A tentative identification of the components was made in function with the relative retention time and the mass spectra with those of The National Institute of Standard and Technology, NIST Willy library data of the GC/MS system.

\subsubsection{In vitro anticancer activity assay of UFOP and FOP methanolic extracts}

The anticancer activity of UFOP and FOP methanolic extracts (which had maximum total phenolic recovery and the highest antioxidant activity among other solvents used in the study) was measured as described by Skehan et al., (1990) and Ibrahim et al., (2015) using the SulfoRhodamine-B stain assay. Cells were incubated with serial dilutions of UFOP and FOP extracts or the reference drug doxorubicin for $48 \mathrm{~h}$. Then the cells were stained with $0.4 \%$ acetic acid SRB solution. Unbound stain was washed with acetic acid. Optical density was measured in an ELISA reader at wave length $545 \mathrm{~nm}$ and the inhibitory concentration $\left(\mathrm{IC}_{50}\right)$ was assayed in comparison with doxorubicin (Ali et al., 2014).

\subsection{Statistical analysis}

The data were reported as mean \pm standard error and analyzed statistically using independent sample $t$-test for comparison between the fermented and unfermented olive pomace groups. Significance was calculated at $\mathrm{p}<0.05$. The correlation coefficient ( $\mathrm{r}$ ) was also calculated by the Bivariate Correlation Test using the SPSS 16.0 Program. 


\section{RESULTS AND DISCUSSION}

Phenolic compounds represent a major class of bioactive compounds. They are considered as potent antioxidants which can improve human health through the prevention of heart diseases, inflammation reduction and lowering the incidence of several diseases such as cancers and diabetes (Khoddami et al., 2013). Research has been intensified aiming to find natural, cheap and renewable sources of bioactive compounds. Therefore, a comparative study between UFOP and OP fermented by $K$. marxianus NRRL Y-8281 was conducted in order to investigate the effect of fermentation on OP total phenolic content and antioxidant activity.

The solvent type which ensures optimum phenolic recovery depends mainly on the chemical properties of the phenolic components contained in the sample at hand (Khoddami et al., 2013). The chemical nature of phenolic compounds present in the sample determines their solubility, which is governed by the number of hydroxyl groups and molecular weight. The solubility of total phenolic compounds in turn determines the polarity of solvent used for total phenolic extraction. Only the mixture of phenolic compounds which is soluble in the solvent selected can be extracted from the sample. Thus, different solvents extract different proportions of total phenolic compounds from the sample giving different total phenolic yields and antioxidant activities. The highest total phenolic recovery is usually achieved using ethanol, methanol and their mixtures with water (Dai and Mumper, 2010). The total phenolic recovery from UFOP and FOP varied in response to different solvents as shown in Figure 1. Solvent type was found to be significantly correlated to phenolic recovery from both UFOP $(r=0.552)$ and FOP $(r=0.462)$.
Polar solvents were more efficient in polyphenolic extraction and gave higher yields. Methanol showed the highest total phenolic recovery (207.35 and $114.78 \mathrm{mg}_{\mathrm{GAE}} / \mathrm{gds}$ for UFOP and FOP, respectively). Other solvents showed lower total phenolic yield and ranged from 30.66 to $90.25 \mathrm{mg}_{\mathrm{GAE}} / \mathrm{gds}$ for both UFOP and FOP. These result resemble those reported by Lafka et al., (2011) to some extent. Different extracts showed different antioxidant activity (Figure 2). This is because the antioxidant activity is influenced by the type and polarity of the extracting solvent as well as the extraction procedure (Lafka et al., 2011). Also, DPPH radical scavenging activity is influenced by both the chemical structure

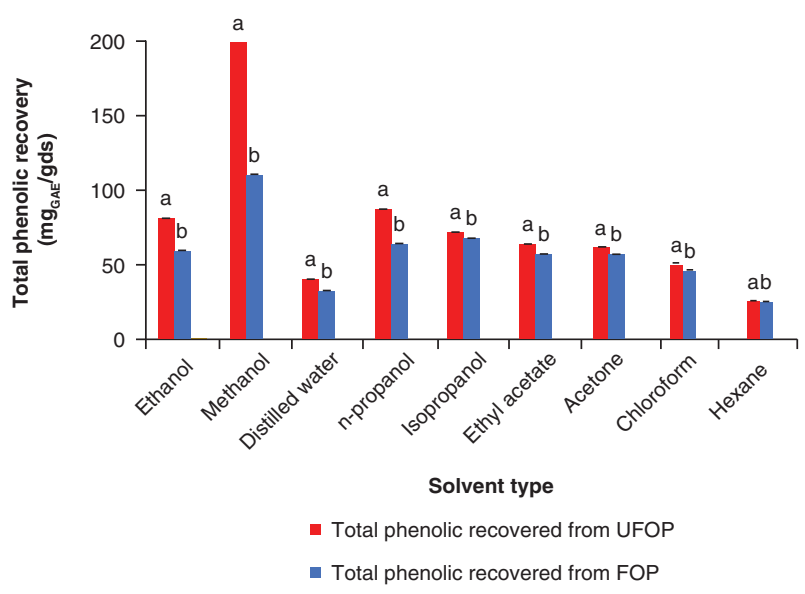

FIGURE 1. Effect of solvent type on total phenolic recovery from unfermented (UFOP) and fermented (FOP) olive pomace.

The experiment was carried out in triplicate. Values are given as mean \pm standard error of three batches. Independent sample $t$-test was used for comparison of means. Means bearing different superscripts are significantly different $(\mathrm{p}<0.05)$.

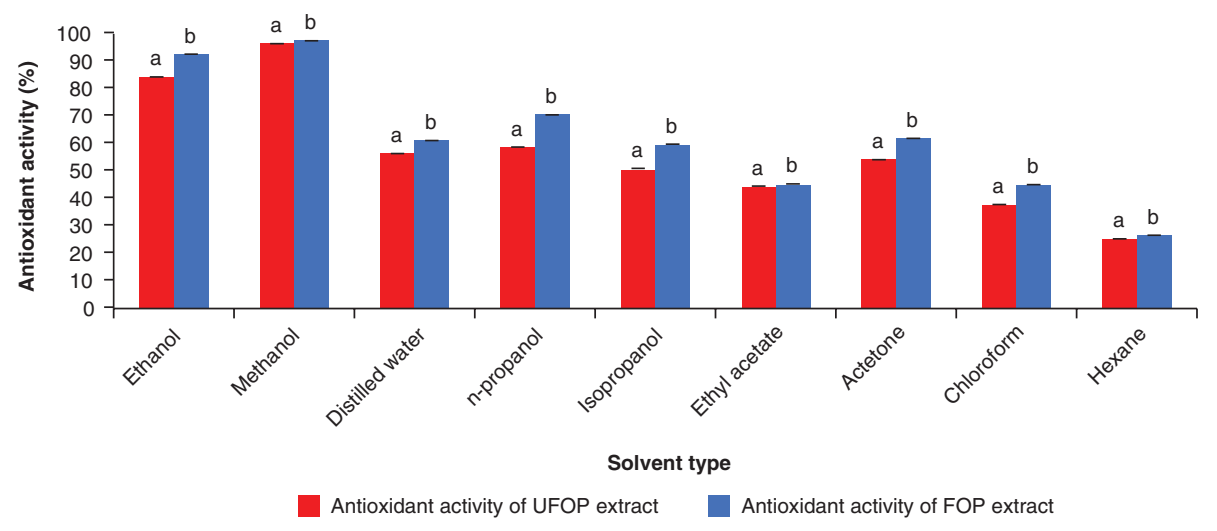

FIGURE 2. DPPH free radical scavenging activity of unfermented (UFOP) and fermented (FOP) olive pomace extracts obtained with different solvents.

The experiment was carried out in triplicate. Values are given as mean \pm standard error of three batches.

Independent sample $t$-test was used for comparison of means. Means bearing different superscripts are significantly different $(\mathrm{p}<0.05$ ). 
of the scavenger compound and the polarity of the reaction medium (Uribe et al., 2014). A significant correlation was found between solvent type and the antioxidant activity of UFOP $(r=0.892)$ extract and FOP extract $(r=0.898)$. Methanolic and ethanolic extracts showed the highest antioxidant activity (methanolic extracts expressed 96 and $97 \%$ and ethanolic extracts expressed 83.87 and $92.1 \%$ for UFOP and FOP, respectively); while the antioxidant activity of ethyl acetate extract (44.05 and 44.92\% for UFOP and FOP, respectively) was surpassed by that of n-propanol (58.28 and $69.96 \%$ for UFOP and FOP, respectively) and iso-propanol (50.53 and $59.39 \%$ for UFOP and FOP, respectively). These findings are in accordance with those reported by Lafka et al., (2011). To explore the influence of total phenolic content on antioxidant activity of OP, the correlation between the antioxidant capacity and total phenolic content was determined. The antioxidant activity of both extracts was significantly correlated with their phenolic content $(r=0.807$ for UFOP, and $r=0.708$ for FOP), which means that phenols represent a high percentage of the antioxidant capacity of olive pomace extract. A correlation between the antioxidant activity and total phenolic content of OP methanolic extract $(r=0.453)$ was previously reported by Uribe et al., (2014) and Alu'datt et al., (2010) $(r=0.746)$. Increasing sample/solvent ratio increased total phenolic recovery. However, the use of large amounts of solvents is not economical and is environmentally polluting due to the increased solvent waste. Moreover, the appropriate amount of extracting solvent should be determined to avoid saturation effects (Dai and Mumper, 2010). The data in Figure 3 shows that a sample/ solvent ratio of 1:10 was optimum for both total phenolic recovery (207.35 and $114.78 \mathrm{mg}_{\mathrm{GAE}} / \mathrm{gds}$ for UFOP and FOP, respectively) and antioxidant activity (96 and 97\% for UFOP and FOP, respectively). The lowest total phenolic yield (74.72 and $71.44 \mathrm{mg}_{\mathrm{GAE}} / \mathrm{gds}$ for UFOP and FOP, respectively) and antioxidant activity (95.69 and $96.4 \%$ for UFOP and FOP, respectively) were obtained when a sample/solvent ratio of 1:5 was applied. This result coincides with the results of Lafka et al., (2011). No significant correlation was found between sample to solvent ratio and total phenolic recovery or antioxidant activity of the extracts. However, the antioxidant activity of the extracts was strongly and significantly correlated to their phenolic contents $(r=0.777$ for UFOP and $r=0.759$ for FOP).

The time of total phenolic extraction is a key factor as it influences both the efficiency of the process through maximizing the extraction yield and the process cost (Aliakbarian et al., 2011). Both extraction time and temperature are responsible for total phenolic solubilization in the extracting solvent and subsequent extraction. However, both factors are also responsible for analyte oxidation and degradation leading to decreased total phenolic recovery. Increasing extraction time and temperature normally leads to increased phenolic recovery, as a result of enhanced analyte solubility, to a certain limit, above which the phenolic yield decreases due to phenolic degradation or oxidation as a result of exhausted extraction times and high temperatures (Khoddami et al., 2013). Total phenolic recovery as well as antioxidant activity were directly proportional to the extraction time till optimum recoveries (207.35 and $114.78 \mathrm{mg}_{\mathrm{GAE}}$ /gds for UFOP and FOP, respectively) and antioxidant activity (96 and 97\% for UFOP and FOP, respectively) were reached at $2 \mathrm{~h}$ of extraction, after which they were inversely proportional to further increase in extraction time

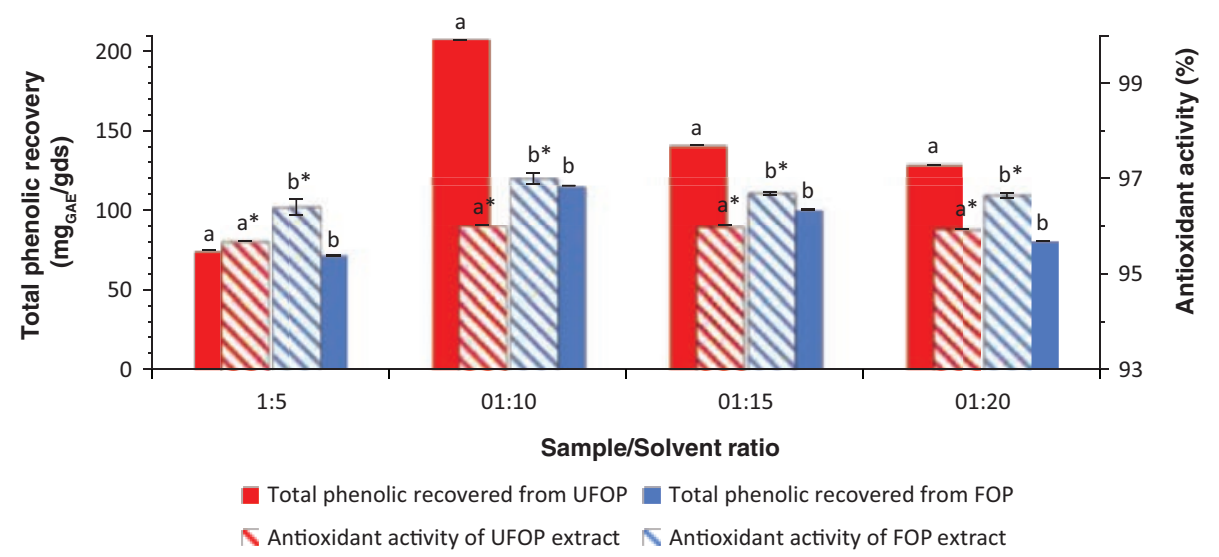

FIGURE 3. Effect of sample to solvent ratio on total phenolic recovery and antioxidant activity from unfermented (UFOP) and fermented (FOP) olive pomace.

The experiment was carried out in triplicate. Values are given as mean \pm standard error of three batches.

Independent sample $t$-test was used for comparison of means. Means bearing different superscripts are significantly different ( $\mathrm{p}<0.05$ ).

${ }^{a}$ and ${ }^{b}$ are significance of means of total phenolic recovered, while ${ }^{\mathrm{a}^{*}}$ and ${ }^{\mathrm{b}^{*}}$ are significance of means of antioxidant activity. 
as shown in Figure 4. Similar behavior was reported by Aliakbarian et al., (2011), who stated a shorter extraction time (90 minutes) due to the application of high pressure and high temperature. While, Lafka et al., (2011) observed an increase in total phenolic recovery with time up to $3 \mathrm{~h}$ of extraction. Alu'datt et al., (2010) reported an optimum extraction time of $12 \mathrm{~h}$ using methanol. The decrease in antioxidant activity of samples with increasing the extraction time beyond the optimum one may be due to a loss in the antioxidant activity of polyphenolic compounds by exposure to temperature, light and oxygen. The same pattern was reported by Lafka et al., (2011). Extraction time was significantly correlated with total phenolic extraction from FOP $(r=-0.626)$, while it was not correlated with total phenolic extraction from UFOP. However, the time of extraction was significantly correlated with the antioxidant activity of both extracts $(r=0.685$ for UFOP and $r=0.624$ for FOP). Meanwhile, the antioxidant activity of both extracts was not correlated with their phenolic contents.

High extraction temperature usually minimizes the extraction duration. However, elevated temperature can cause phenolic degradation (Dai and Mumper, 2010). Increasing the extraction temperature not only increases total phenolic solubility and mass transfer rate (diffusion coefficient), but also decreases the viscosity and surface tension of the solvent used helping the solvent to penetrate the sample particles leading to an improved total phenolic recovery. Also, high temperature disrupts the strong solute-matrix interactions stabilized by VanderWaals forces, hydrogen bonding and dipole attractions, thus allowing for better recovery (Aliakbarian et al., 2011). However, many phenolic compounds could be lost during their extraction at high temperature for prolonged time due to their oxidation and hydrolysis leading to a decreased recovery (Dai and Mumper, 2010). The data in Figure 5 shows that total phenolic recovery as well as antioxidant activity increased by increasing extraction temperature up to $50{ }^{\circ} \mathrm{C}\left(207.35\right.$ and $114.78 \mathrm{mg}_{\mathrm{GAE}} / \mathrm{gds}$ expressing $96 \%$ and $97 \%$ antioxidant activity for UFOP and FOP, respectively) and then started to fall. This positive relationship between total phenolic recovery from OP and temperature has been confirmed by other authors. Alu'datt et al., (2010) reported a continuous increase in total phenolic recovery and antioxidant activity with temperature giving maximum recovery at $70{ }^{\circ} \mathrm{C}$ and maximum antioxidant activity at $60{ }^{\circ} \mathrm{C}$. An optimum temperature of $180^{\circ} \mathrm{C}$, giving a maximum total phenolic recovery using a high pressure-high temperature reactor was recorded by Aliakbarian et al., (2011). On the other hand, Shahidi and Naczk (2003) observed that the extraction temperature was directly proportional to the total phenolic recovery, while it was inversely proportional to the antioxidant activity. Extraction temperature was strongly correlated with phenolic recovery $(r=-0.766$ for UFOP and $r=-0.813$ for FOP) but not correlated with the antioxidant activity of the extracts. However, the total phenolic content of both extracts was significantly correlated with their antioxidant activity $(r=0.601$ for UFOP and $r=0.744$ for FOP). Alu'datt et al., (2010) affirmed that the total phenolic compound content of olive pomace extracts varied significantly $(\mathrm{p}<0.05)$ for the tested temperature range.

Further studies were conducted for the determination of the best UFOP and FOP methanolic extract concentration which gives the optimum phenolic content to express maximum antioxidant activity. The total phenolic content of the methanolic extract of UFOP and FOP with various concentrations $(2-10 \mathrm{mg} / \mathrm{ml})$ is shown in Figure 6 .

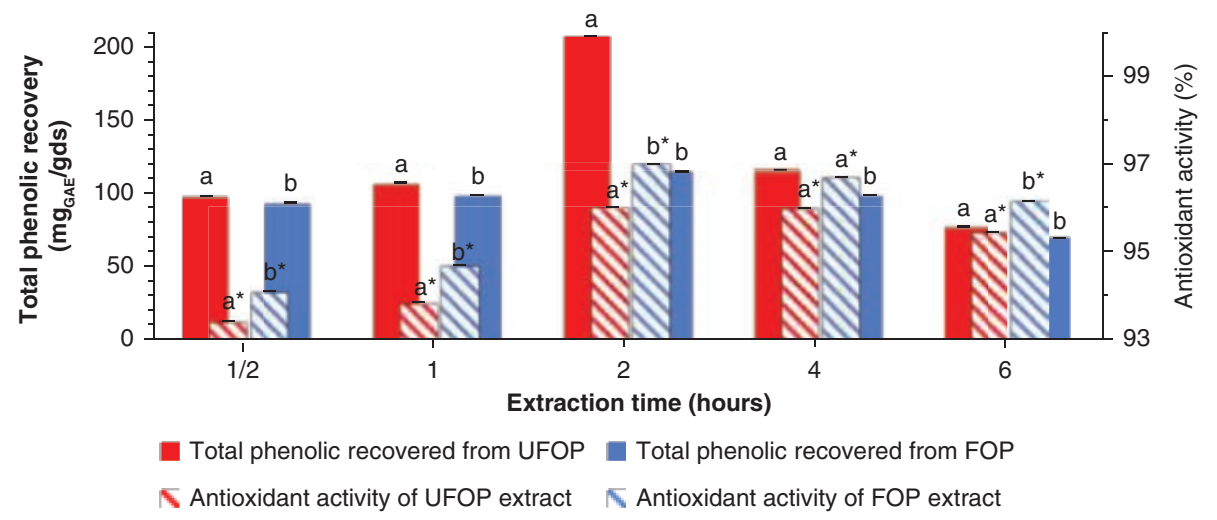

FIGURE 4. Effect of extraction time on total phenolic recovery and antioxidant activity from unfermented (UFOP) and fermented (FOP) olive pomace.

The experiment was carried out in triplicate. Values are given as mean \pm standard error of three batches.

Independent sample $t$-test was used for comparison of means. Means bearing different superscripts are significantly different ( $\mathrm{p}<0.05$ ).

${ }^{a}$ and ${ }^{b}$ are significance of means of total phenolic recovered, while ${ }^{\mathrm{a}^{*}}$ and ${ }^{\mathrm{b}^{*}}$ are significance of means of antioxidant activity. 


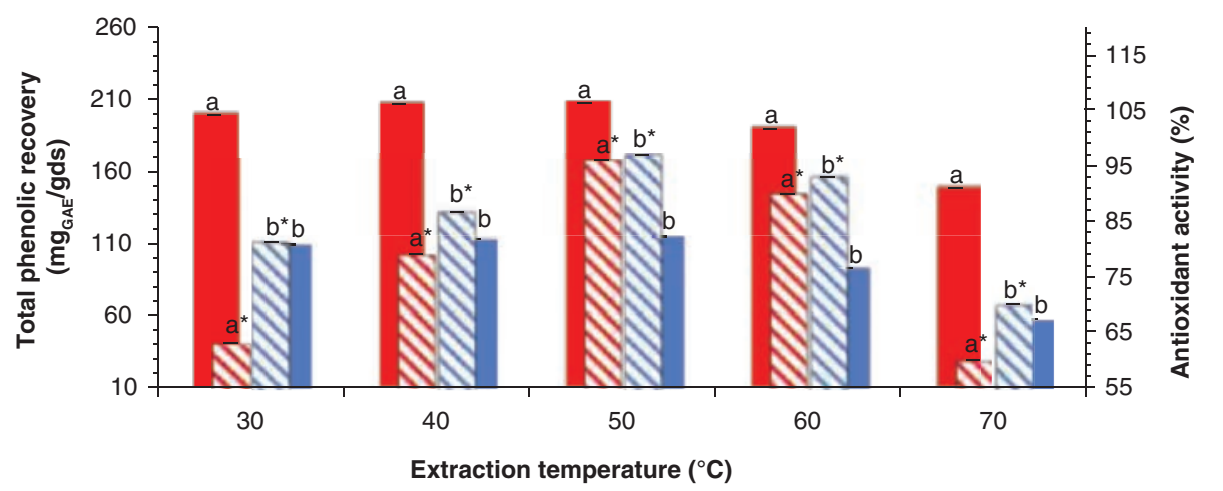

\footnotetext{
Total phenolic recovered from UFOP Total phenolic recovered from FOP

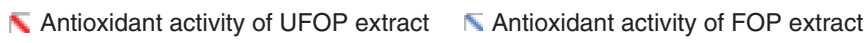

FIGURE 5. Effect of extraction temperature on total phenolic recovery and antioxidant activity from unfermented (UFOP) and fermented (FOP) olive pomace.

The experiment was carried out in triplicate. Values are given as mean \pm standard error of three batches.

Independent sample $t$-test was used for comparison of means. Means bearing different superscripts are significantly different $(\mathrm{p}<0.05)$.

${ }^{\mathrm{a}}$ and ${ }^{\mathrm{b}}$ are significance of means of total phenolic recovered, while ${ }^{\mathrm{a}^{*}}$ and ${ }^{\mathrm{b} *}$ are significance of means of antioxidant activity.

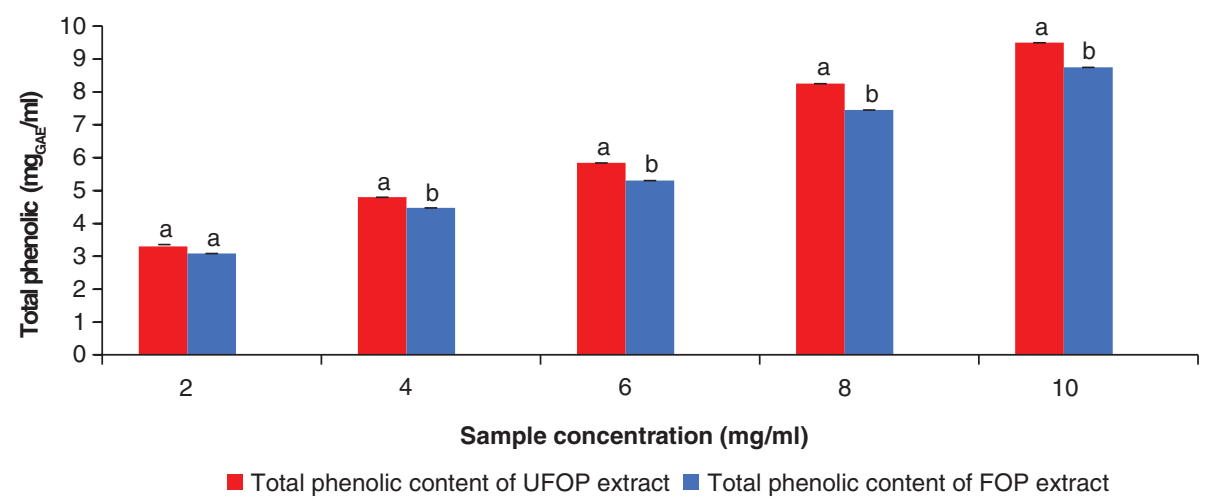

FIGURE 6. Total phenolic content of unfermented (UFOP) and fermented (FOP) olive pomace methanolic extracts at different concentrations.

The experiment was carried out in triplicate. Values are given as mean \pm standard error of three batches.

Independent sample $t$-test was used for comparison of means. Means bearing different superscripts are significantly different $(\mathrm{p}<0.05)$.

The results showed that the higher the concentration used for the assay, the higher the total phenolic content. However, the total phenolic content of the FOP extract at all studied concentrations was lower than that of the UFOP extract indicating OP polyphenol degradation by $K$. marxianus fermentation. The antioxidant activities of different extract concentrations $(2-10 \mathrm{mg} / \mathrm{ml})$ were measured using DPPH radical scavenging activity and $\beta$-carotene/ linoleic acid system assays. The results gathered in Figure 7 show that the free radical scavenging activities of both extracts were concentration-dependent. There was a gradual increase in the DPPH radical scavenging activity of both extracts with an increase in the extract concentration till maximum radical scavenging activities (96.0 and $97.0 \%$ for UFOP and FOP, respectively) were reached at extract concentrations of $4 \mathrm{mg} / \mathrm{ml}$ for both extracts. Beyond this concentration a decrease in their activities was observed. Figure 8 shows that the inhibition of lipid peroxidation activity of both extracts was also concentration-dependent. The inhibition of lipid peroxidation activity in both extracts increased gradually with an increase in the extract concentration till maximum inhibition of lipid peroxidation activity (44.5 and $68.9 \%$ for UFOP and FOP, respectively) was reached at the extract concentration of $4 \mathrm{mg} / \mathrm{ml}$ for both extracts and above this concentration a decrease in their activities was observed. The decrease in the antioxidant activity in both extracts observed for 


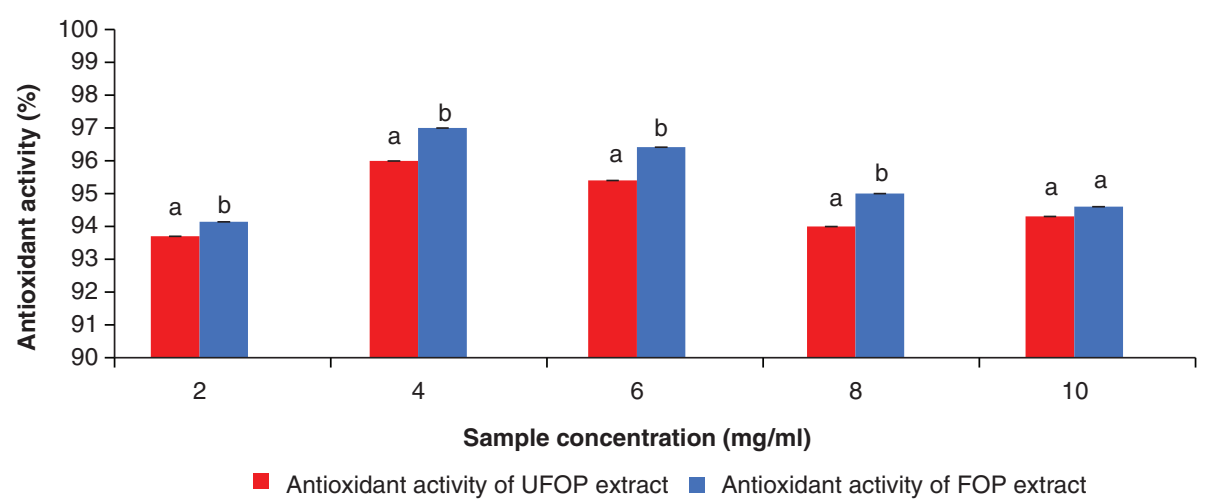

FIGURE 7. DPPH free radical scavenging activity of different concentrations of unfermented (UFOP) and fermented (FOP) olive pomace methanolic extracts.

The experiment was carried out in triplicate. Values are given as mean \pm standard error of three batches. Independent sample $t$-test was used for comparison of means. Means bearing different superscripts are significantly different $(\mathrm{p}<0.05)$.

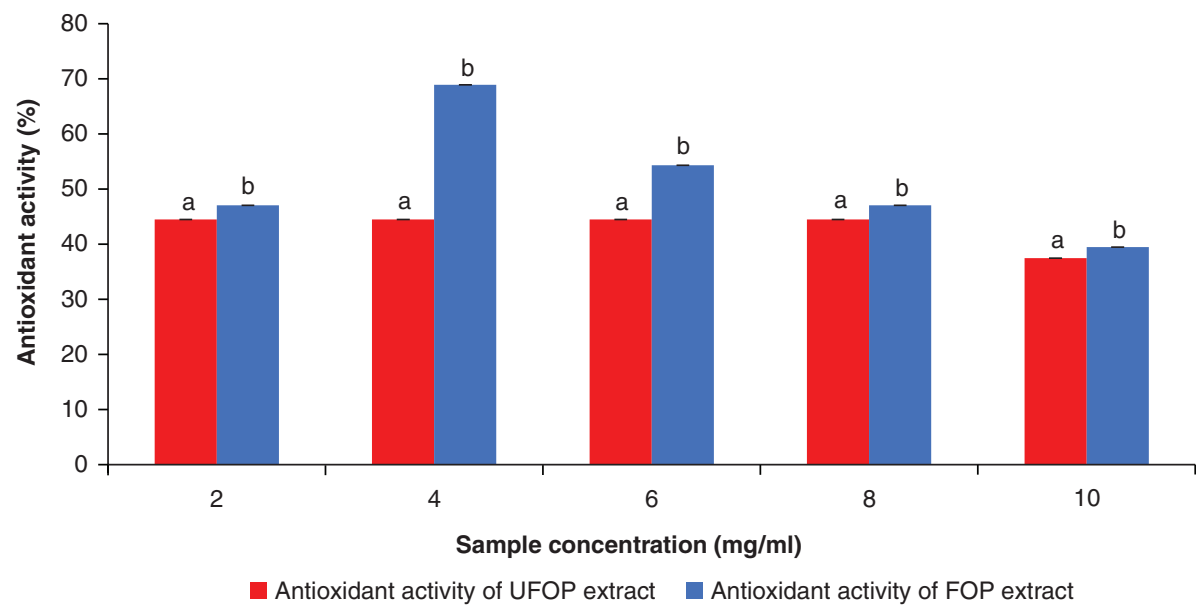

FIGURE 8. Antioxidant activity of different concentrations of unfermented (UFOP) and fermented (FOP) olive pomace methanolic extracts using $\beta$-carotene / linoleic acid system assay

The experiment was carried out in triplicate. Values are given as mean \pm standard error of three batches.

Independent sample $t$-test was used for comparison of means. Means bearing different superscripts are significantly different $(\mathrm{p}<0.05)$.

both the DPPH radical scavenging system and $\beta$ carotene/linoleic acid system can be attributed to the pro-oxidant activity of phenolic compounds. The concentration of the phenolic-rich extract was significantly correlated with the total phenolic content $(r=$ 0.992 and 0.991 for UFOP and FOP, respectively) and to the antioxidant activity in the $\beta$-carotene/linoleic acid system assay $(r=-0.707$ and -0.526 for UFOP and FOP, respectively), although it was not correlated with the DPPH radical scavenging activity of both extracts. The phenolic content of the UFOP extract was significantly different from that of the FOP extract at sample concentrations ranging from 4 to $10 \mathrm{mg} / \mathrm{ml}(\mathrm{p}<0.05)$, which indicates phenolic degradation of OP by fermentation. No significant difference was found between their phenolic contents at a concentration of $2 \mathrm{mg} / \mathrm{ml}$. Also, a significant difference $(p<0.05)$ was found between the DPPH radical scavenging activity of UFOP and FOP methanolic extracts at different concentrations, indicating an enhanced radical antioxidant activity of OP after fermentation. In addition, a significant difference $(p<0.05)$ was found between both extracts with regards to their activity in the $\beta$-carotene/linoleic acid system, suggesting enhanced pomace protecting activity against lipid peroxidation after fermentation.

The optimization of extraction parameters resulted in a maximum total phenolic yield of 207.35 and $114.78 \mathrm{mg}_{\mathrm{GAE}} / \mathrm{gds}$ for UFOP and FOP, 
respectively, using methanol with a sample/solvent ratio of $1: 10(\mathrm{~V} / \mathrm{W})$ at $50^{\circ} \mathrm{C}$ for $2 \mathrm{~h}$ at a sample concentration of $4 \mathrm{mg} / \mathrm{ml}$. Aliakbarian et al., (2011) obtained a maximum total phenolic yield of 45.2 $\mathrm{mg}_{\mathrm{GAE}} / \mathrm{gds}$ using methanol with a ratio of $10: 1$ (V/W) at $180^{\circ} \mathrm{C}$ for 90 minutes under an appropriate pressure. While Alu'datt et al. (2010) reported a maximum total phenolic yield ( $\left.4.4 \mathrm{mg}_{\mathrm{GAE}} / \mathrm{gds}\right)$ using methanol $(25: 1 \mathrm{~V} / \mathrm{W})$ at $70{ }^{\circ} \mathrm{C}$ for $12 \mathrm{~h}$. Suárez et al., (2009) reported a maximum total phenolic yield of $2.5 \mathrm{mg}$ phenol/g using ethanol/water $(80: 20)$ at 80 ${ }^{\circ} \mathrm{C}$. From the results obtained it can be concluded that fermentation of OP for $48 \mathrm{~h}$ using $K$. marxianus NRRL Y- 8281 led to a decrease in total phenolic content from $207.35 \mathrm{mg}_{\mathrm{GAE}} / \mathrm{gds}$ to $114.78 \mathrm{mg}_{\mathrm{GAE}} /$ gds for UFOP and FOP, respectively (representing $44.64 \%$ reduction in total phenolic content), along with a small increase in DPPH radical scavenging activity from 96.0 to $97.0 \%$ for UFOP and FOP, respectively. The reduction in total phenolic content of OP by fermentation was also confirmed by Fadel and El-Ghonemy (2015) who stated a reduction in OP total phenolic content from $3.1 \%$ to $0.92 \%$ using A. oryzae FK-923 for 7 days.

The reduction in total phenolic quantity while maintaining a nearly constant or slightly elevated DPPH radical scavenging activity can be attributed to the altered quality of phenolic compounds contained in the FOP. This finding confirms that total phenolic content does not necessarily increase simultaneously with DPPH scavenging activity as the later depends mainly on the quality rather than quantity of the phenolic compounds present in the extract. In their study, Uribe et al., (2014) found that the total phenolic content was inversely proportional to the antioxidant activity, suggesting that a detailed analysis of the quality of polyphenolic compounds present in the sample is a must to identify the compounds responsible for the high antioxidant activity in samples. In order to present a more precise explanation for total phenolic content-independent increase in the antioxidant activity of FOP, further investigation and identification of individual compounds present in both UFOP and FOP was conducted by GC/MS analysis. The data obtained from the GC/MS analysis (Table 1) revealed that the major compounds that could be found in the methanolic extract of UFOP were identified as oleic acid methyl ester (53.04\%), oleic acid ethyl ester $(14.17 \%)$ and methyl palmitate $(11.03 \%)$.

The dominant compound found in UFOP methanolic extract, methyl oleate, was reported to have antioxidant and anticancer activities (Akpuaka et al., 2013). It has also been reported to serve as an endogenous ligand to peroxisome proliferator-activated receptors. The peroxisome proliferator- activated receptors are a group of nuclear receptor proteins that function as transcription factors regulating the expression of genes involved in the regulation of carbohydrate, lipid and protein metabolism, energy homeostasis, cellular differentiation, tumorigenesis, lung diseases, obesity, diabetes, neurodegenerative disorders, fertility and reproduction (Tyagi et al., 2011). The second dominant compound found in UFOP methanolic extract, ethyl oleate, is a fatty acid ester formed by the condensation of oleic acid and ethanol. It is considered an important compound in the food industry as a food additive in addition to its use for drying fruit. In the pharmaceutical industry, ethyl oleate is used as a solvent for pharmaceutical drug preparations involving lipophilic substances such as steroids (Aly et al., 2016). Methyl palmitate is considered an inhibitor to 5-Alpha reductase, an enzyme whose inhibitors can be used in benign prostatic hyperplasia and prostate cancer (Hema et al., 2011; Akpuaka et al., 2013). It is also considered as a hypocholesterolemic factor and antioxidant (Hema et al., 2011).

The results obtained from the GC/MS analysis of UFOP methanolic extract are in line with those obtained by other researchers. Ethyl oleate and methyl oleate were detected in OP by Kuley et al., (2017). In addition, Schievano et al., (2015) reported the presence of methyl palmitate in OP. On the other hand, carvacrol $(4.9 \%)$, thymol $(2.97 \%)$, eugenol $(2.87 \%)$ and caryophyllene oxide $(1.36 \%)$ were detected only in the methanolic extract of FOP (Table 2). However, oleic acid methyl ester $(47.42 \%)$ and oleic acid ethyl ester $(11.93 \%)$ were the major components in the extract followed by methyl- isopalmitate $(9.75 \%)$. Carvacrol and thymol are monoterpenoid phenolic compounds produced naturally by some plants (Özkan and Erdoğan, 2011). Several in vitro and in vivo studies suggest that

TABLE 1. Compounds identified from the major retention peaks obtained by GC/MS analysis of unfermented olive pomace (UFOP) methanolic extract

\begin{tabular}{|c|c|c|c|c|}
\hline Compound & Synonyms & Retention time (minutes) & Molecular weight & Area $(\%)$ \\
\hline Hexadecanoic acid, methyl ester & $\begin{array}{l}\text { Palmitic acid, methyl ester } \\
\text { Methyl palmitate }\end{array}$ & 25.11 & 270 & 11.03 \\
\hline 9-Octadecenoic acid, methyl ester & $\begin{array}{l}\text { Oleic acid, methyl ester } \\
\text { Methyl oleate }\end{array}$ & 27.13 & 296 & 53.04 \\
\hline 9-Octadecenoic acid, ethyl ester & $\begin{array}{l}\text { Oleic acid, ethyl ester } \\
\text { Ethyl oleate }\end{array}$ & 27.87 & 310 & 14.17 \\
\hline
\end{tabular}


TABLE 2. Compounds identified from the major retention peaks obtained by GC/MS analysis of fermented olive pomace (FOP) methanolic extract

\begin{tabular}{|c|c|c|c|c|}
\hline Compound & Synonyms & Retention time (minutes) & Molecular weight & Area $(\%)$ \\
\hline Phenol,2-methyl-5-(1-methyl-ethyl) & Carvacrol & 16.58 & 150 & 4.90 \\
\hline Phenol,5-methyl-2-(1-methyl-ethyl) & Thymol & 16.70 & 150 & 2.97 \\
\hline Phenol,2-methoxy-4-(2-propenyl) & Eugenol & 17.94 & 164 & 2.87 \\
\hline Caryophyllene -oxide & - & 20.65 & 220 & 1.36 \\
\hline $\begin{array}{l}\text { Pentadecanoic acid, 14-methyl-, } \\
\text { methyl ester }\end{array}$ & Methyl-isopalmitate & 25.08 & 270 & 9.75 \\
\hline 9-Octadecenoic acid, methyl ester & $\begin{array}{l}\text { Oleic acid, methyl ester } \\
\text { Methyl oleate }\end{array}$ & 27.13 & 296 & 47.42 \\
\hline 9-Octadecenoic acid, ethyl ester & $\begin{array}{l}\text { Oleic acid, ethyl ester } \\
\text { Ethyl oleate }\end{array}$ & 27.88 & 310 & 11.93 \\
\hline
\end{tabular}

carvacrol has anti-inflammatory, immunomodulatory, antioxidant and anticancer activities. It also possesses anti- obesity, hepatoprotective, gastroprotective, neuroprotective (anti-Alzheimer disease) and platelet antiaggregating activities. Clinically, thymol is used as antipyretic, antispasmodic, antihyperlipidemic, antihyperglycemic, gastroprotective, hepatoprotective, antioxidant, analgesic, anesthetic, antiepileptic and anti-inflammatory (Özkan and Erdoğan, 2011). Eugenol is an organic phenolic phytochemical. Regarding its minimal toxicity and low side effects, eugenol is widely applied in the pharmaceutical industry, food industry (as flavoring agent), in cosmetics and in dentistry in addition to being an antiparasitic and insect repellent (Kong et al., 2014). Caryophyllene oxide is an oxygenated sesquiterpene that expresses numerous pharmacological effects including antimicrobial, immunomodulatory, antirheumatic, anti-arthritic and antipyretic activities. It is also considered as anti-inflammatory, anti-platelet aggregation, antioxidant and anticancer agent (Park et al., 2011). Thymol, carvacrol, eugenol and caryophyllene oxide are classified as aromatic compounds which are volatile compounds and have odor or taste. The detection of these aromatic constituents in the methanolic extract of FOP can be attributed to their synthesis and excretion by $K$. marxianus. This strain has been reported to produce aromatic compounds such as monoterpenes, fruit esters, ketones, carboxylic acids, furans and alcohols (Wilkowska et al., 2015). Although several yeast strains have been reported for the production of aromatic substances, only those stated as GRAS, such as $K$. marxianus, can find industrial applications (Fonseca et al., 2008). These findings open new prospects for the possibility of utilizing $K$. marxianus fermented $\mathrm{OP}$ in food, feed and pharmaceutical industries.

As shown in Figure 9, the antiproliferative activity of UFOP and FOP methanolic extracts was tested using the SRB assay in MCF-7, HepG2, A549, Hela, PC3 and HCT116 cancer cell lines as well as the normal human melanocyte, HFB4. For comparison, treatment with doxorubicin was used as a positive control and treatment with DMSO was used as a negative control. The tumor cells showed normal growth in the culture system. In addition, UFOP and FOP exhibited no activity against the growth of the normal HFB4 cell line. From the results, it is evident that although UFOP and FOP methanolic extracts displayed potent anticancer activity against HepG2 and MCF-7, they had moderate activity against PC3 and HCT116 cell lines. In addition, they did not exert any activity against lung A549 or Hela cancer cell lines. In the case of HepG2, UFOP and FOP exerted antiproliferative activity with $\mathrm{IC}_{50}$ values of $22.65 \pm 2.48$ and $20.00 \pm 2.32 \mu \mathrm{g} / \mathrm{ml}$ near the $\mathrm{IC}_{50}$ of the reference drug, doxorubicin ( $\left.\mathrm{IC}_{50}: 20.30 \pm 2.34 \mu \mathrm{g} / \mathrm{ml}\right)$. For MCF-7, the $\mathrm{IC}_{50}$ was $25.50 \pm 2.67$ and $23.25 \pm$ $2.43 \mu \mathrm{g} / \mathrm{ml}$ (doxorubicin $\mathrm{IC}_{50}: 24.00 \pm 2.72 \mu \mathrm{g} / \mathrm{ml}$ ). For PC3 the $\mathrm{IC}_{50}$ was $38.00 \pm 5.06$ and $32.90 \pm$ $4.62 \mu \mathrm{g} / \mathrm{ml}$ for UFOP and FOP, respectively (doxorubicin $\mathrm{IC}_{50}: 18.47 \pm 2.00 \mu \mathrm{g} / \mathrm{ml}$ ). For HCT116 the $\mathrm{IC}_{50}$ was $33.88 \pm 3.96$ and $32.40 \pm 4.13 \mu \mathrm{g} / \mathrm{ml}$ for UFOP and FOP, respectively (doxorubicin $\mathrm{IC}_{50}$ : $19.83 \pm 2.11 \mu \mathrm{g} / \mathrm{ml})$. In conclusion, it is clear that, while the $\mathrm{IC}_{50}$ of both UFOP and FOP was close to the value of the doxorubicin in the two cell lines (HepG2 and MCF-7), FOP was more potent than UFOP in the four cell lines (MCF-7, HepG2, PC3 and HCT116). This enhanced anticancer activity after fermentation can be attributed to the increased concentration of accumulated gallic acid (Fathy et al., 2018) or the production of carvacrol, thymol, eugenol and caryophyllene oxide (Table 2). Gallic acid was reported to have cytotoxic effects against prostate cancer-3 (PC-3), HeLa and lung A549 cancer cell lines (Park and Kim, 2013). Also, eugenol has antioxidant and anticancer activities showing chemopreventive properties which are better than chemically synthesized anticancer drugs. It can induce apoptosis in some cancers including cervical carcinoma, gastric cancer, melanoma, prostate cancer, skin tumors, osteosarcoma and 


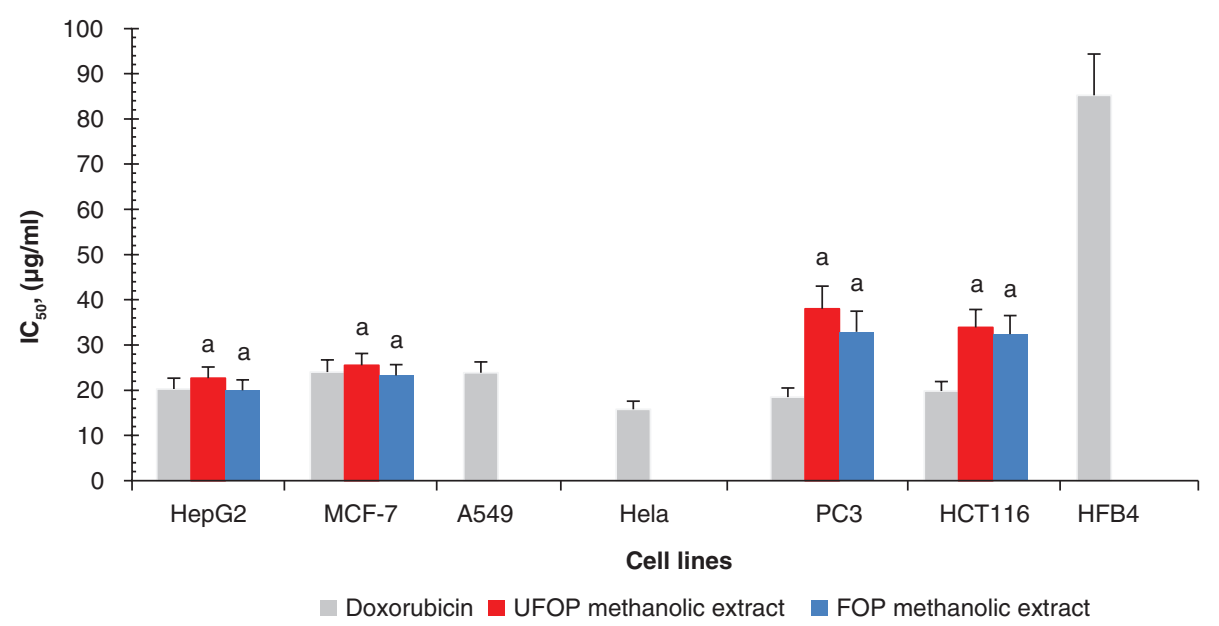

FIGURE 9. In vitro anticancer activity $\left(\mathrm{IC}_{50}, \mu \mathrm{g} / \mathrm{ml}\right)$ of unfermented (UFOP) and fermented (FOP) olive pomace methanolic extracts in different human cell lines.

The experiment was carried out in triplicate. Values are given as mean \pm standard error of three batches.

Independent sample $t$-test was used for comparison of means. ${ }^{a}$ is significantly different from doxorubicin treated group ( $\mathrm{p}<0.05$ ).

leukemia (Kong et al., 2014). Moreover, caryophyllene oxide was reported as a potent antioxidant and anticancer which presents cytotoxic activity against HepG2 and HeLa cancer cell lines (Jun et al., 2011). Caryophyllene oxide has also been reported to have anticancer activity against prostate and breast cancers (Park et al., 2011).

\section{CONCLUSIONS}

The SSF of OP by K. marxianus is a new ecofriendly valorization technique that enables the production of valuable bioactive compounds with promising antioxidant and anticancer activities. This is the first report concerning the effects of FOP extract against different cancer cell lines. However, few reports have been conducted concerning the anticancer activity of UFOP extracts against different cell lines which show potent anticancer activity against P815 mastocytoma murine, HepG2 human hepatoma and MDA-MB-231 breast cancer cell lines. Regarding its high poly phenolic content, OP can be considered as a cheap and renewable source of pharmaceutical compounds rather than an environmentally polluting agro-industrial waste.

\section{ACKNOWLEDGEMENT}

This work was supported by the National Research Centre, Egypt (Project no.11010343).

\section{CONFLICT OF INTEREST}

The authors declare that there is no conflict of interest in the study.

\section{REFERENCES}

Akpuaka A, Ekwenchi M, Dashak D, Dildar A. 2013. Biological activities of characterized isolates of n-hexane extract of Azadirachta indica A. Juss (Neem) leaves. NY Sci. J. 6, 119-124.

Ali MM, Mahmoud AE, Abdel-Halim AH, Fyiad AA. 2014. Anti-cancer effect of some prepared sulfated oligosaccharides on three different human cancer cell lines. Asian Journal of Pharmaceutical and Clinical Research 7, 168-176.

Aliakbarian B, Casazza AA, Perego P. 2011. Valorization of olive oil solid waste using high pressure-high temperature reactor. Food Chem. 128, 704-710. https://doi.org/10.1016/j. foodchem.2011.03.092

Alu'datt MH, Alli I, Ereifej K, Alhamad M, Al-Tawaha AR, Rababah T. 2010. Optimisation, characterisation and quantification of phenolic compounds in olive cake. Food Chem. 123, 117-122. https://doi.org/10.1016/j.foodchem.2010.04.011

Aly AA, Maraei RW, Ali HG. 2016. Fatty Acids Profile and Chemical Composition of Egyptian Moringa oleifera Seed Oils. J. Am. Oil Chem. Soc. 93, 397-404. https://doi. org/10.1007/s11746-015-2781-6

Ciriminna R, Meneguzzo F, Fidalgo A, Ilharco LM, Pagliaro M. 2016. Extraction, benefits and valorization of olive polyphenols. Eur. J. Lipid Sci. Technol. 118, 503-511. https://doi. org/10.1002/ejlt.201500036

Dai J, Mumper RJ. 2010. Plant phenolics: extraction, analysis and their antioxidant and anticancer properties. Molecules 15, 7313-7352. https://doi.org/10.3390/molecules15107313

El Malah T, Nour HF, Nayl A, Elkhashab R, Abdel-Megeid FM, Ali MM. 2016. Anticancer Evaluation of Tris(triazolyl)triazine Derivatives Generated via Click Chemistry. Aust. J. Chem. 69, 905-910. https://doi.org/10.1071/ch16006

Fadel M, El-Ghonemy DH. 2015. Biological fungal treatment of olive cake for better utilization in ruminants nutrition in Egypt. Int. J. Recycl. Org. Waste Agric. 4, 261-271. https:// doi.org/10.1007/s40093-015-0105-3

Fathy SA, Mahmoud AE, Rashad MM, Ezz MK, Mohammed AT. 2018. Improving the nutritive value of olive pomace by solid state fermentation of Kluyveromyces marxianus with simultaneous production of gallic acid. Int. J. Recycl. Org. Waste Agric. 1-7. Available online on $5^{\text {th }}$ Febrauary. https:// doi.org/10.1007/s40093-018-0199-5

Fonseca GG, Heinzle E, Wittmann C, Gombert AK. 2008. The yeast Kluyveromyces marxianus and its biotechnological 
potential. Appl. Microbiol. Biotechnol. 79, 339-354. https:// doi.org/10.1007/s00253-008-1458-6

Hema R, Kumaravel S, Alagusundaram K. 2011. GC/MS determination of bioactive components of Murraya koenigii. $J$. Am. Sci. 7, 80-83.

Ibrahim NM, Yosef HA, Ewies EF, Mahran MR, Ali MM, Mahmoud AE. 2015. Synthesis and Antitumor Evaluation of New Heterocycles Derived from 3-Methyl-2- benzothiazolinone Hydrazone. J. Braz. Chem. Soc. 26, 1086-1097. https://doi.org/10.5935/0103-5053.20150071

Jun NJ, Mosaddik A, Moon JY, Jang K-C, Lee D-S, Ahn KS, Cho SK. 2011. Cytotoxic activity of $\beta$ - caryophyllene oxide isolated from Jeju Guava (Psidium cattleianum Sabine) leaf. Rec. Nat. Prod. 5, 242-246.

Juntachote T, Berghofer E. 2005. Antioxidative properties and stability of ethanolic extracts of Holy basil and Galangal. Food Chem. 92, 193-202. https://doi.org/10.1016/j. foodchem.2004.04.044

Khoddami A, Wilkes MA, Roberts TH. 2013. Techniques for analysis of plant phenolic compounds. Molecules 18, 2328-2375. https://doi.org/10.3390/molecules 18022328

Kong X, Liu X, Li J, Yang Y. 2014. Advances in pharmacological research of eugenol. Curr. Opin. Complement Alternat. Med. 1, 8-11.

Kuley E, Durmus M, Balikci E, Ucar Y, Regenstein JM, ÖzoĞul F. 2017. Fish spoilage bacterial growth and their biogenic amine accumulation: Inhibitory effects of olive by- products. Int. J. Food Prop. 20, 1029-1043. https://doi.org/10.10 80/10942912.2016.1193516

Lafka T-I, Lazou AE, Sinanoglou VJ, Lazos ES. 2011. Phenolic and antioxidant potential of olive oil mill wastes. Food Chem. 125, 92- 98. https://doi.org/10.1016/j. foodchem 2010.08 .041

Mahmoud AE, Ali MM. 2012. Attenuation the side effects of adriamycin-induced cardiotoxicity and nephrotoxicity in rats by fermented Punica granatum (pomegranate) peel extract. Int. J. Res. Pharm. Sci. 3, 29-37.

Mahmoud AE, Fathy SA, Rashad MM, Ezz MK, Mohammed AT. 2018. Purification and characterization of a novel tannase produced by Kluyveromyces marxianus using olive pomace as solid support, and its promising role in gallic acid production. Int. J. Biol. Macromol. 107, 2342-2350. https://doi.org/10.1016/j.ijbiomac.2017.10.117

Mensor LL, Menezes FS, Leitão GG, Reis AS, Santos TCd, Coube CS, Leitão SG. 2001. Screening of Brazilian plant extracts for antioxidant activity by the use of DPPH free radical method. Phytother. Res. 15, 127-130. https://doi. org/10.1002/ptr.687

Özkan A, Erdoğan A. 2011. A comparative evaluation of antioxidant and anticancer activity of essential oil from Origanum onites (Lamiaceae) and its two major phenolic components. Turkish J. Biol. 35, 735-742.

Park, WH, Kim SH. 2013. MAPK inhibitors augment gallic acidinduced A549 lung cancer cell death through the enhancement of glutathione depletion. Onc. Rep. 30, 513-519. https://doi.org/10.3892/or.2013.2447
Park K-R, Nam D, Yun H-M, Lee S-G, Jang H-J, Sethi G, Cho SK, Ahn KS. 2011. $\beta$ - Caryophyllene oxide inhibits growth and induces apoptosis through the suppression of $\mathrm{PI} 3 \mathrm{~K} / \mathrm{AKT} / \mathrm{mTOR} / \mathrm{S} 6 \mathrm{~K} 1$ pathways and ROS-mediated MAPKs activation. Cancer Lett. 312, 178-188. https://doi. org/10.1016/j.canlet.2011.08.001

Quettier-Deleu C, Gressier B, Vasseur J, Dine T, Brunet C, Luyckx M, Cazin M, Cazin J-C, Bailleul F, Trotin F. 2000. Phenolic compounds and antioxidant activities of buckwheat (Fagopyrum esculentum Moench) hulls and flour. J. Ethnopharmacol. 72, 35-42. https://doi.org/10.1016/ s0378-8741(00)00196-3

Ramos P, Santos SA, Guerra ÂR, Guerreiro O, Felício L, Jerónimo E, Silvestre AJ, Neto CP, Duarte M. 2013. Valorization of olive mill residues: Antioxidant and breast cancer antiproliferative activities of hydroxytyrosol-rich extracts derived from olive oil by- products. Ind. Crops Prod. 46, 359-368. https://doi.org/10.1016/j.indcrop.2013. 02.020

Ranchal I, de Castro M, Muntané J. 2014. Olive Leaves and Mill Waste Exert Anti-Tumoral Properties in Hepatoma Cell Line. J. Carcinog. Mutagen. 5, 1-10. https://doi.org/ 10.4172/2157-2518.1000170

Schievano A, Adani F, Buessing L, Botto A, Casoliba EN, Rossoni M, Goldfarb JL. 2015. An integrated biorefinery concept for olive mill waste management: supercritical $\mathrm{CO}_{2}$ extraction and energy recovery. Green Chem. 17, 2874-2887. https://doi.org/10.1039/c5gc00076a

Shahidi F, Naczk M. 2003. Phenolics in food and nutraceuticals. CRC press.

Skehan P, Storeng R, Scudiero D, Monks A, McMahon J, Vistica D, Warren JT, Bokesch H, Kenney S, Boyd MR. 1990. New colorimetric cytotoxicity assay for anticancerdrug screening. J. Natl. Cancer Inst. 82, 1107-1112. https:// doi.org/10.1093/jnci/82.13.1107

Suárez M, Romero M-P, Ramo T, Macià A, Motilva M-J. 2009. Methods for preparing phenolic extracts from olive cake for potential application as food antioxidants. J. Agric. Food Chem. 57, 1463-1472. https://doi.org/10.1021/jf8032254

Tyagi S, Gupta P, Saini AS, Kaushal C, Sharma S. 2011. The peroxisome proliferator-activated receptor: A family of nuclear receptors role in various diseases. J. Adv. Pharm. Technol. Res. 2, 236-240. https://doi.org/10.4103/22314040.90879

Uribe E, Lemus-Mondaca R, Vega-Gálvez A, Zamorano M, Quispe-Fuentes I, Pasten A, Di Scala K. 2014. Influence of process temperature on drying kinetics, physicochemical properties and antioxidant capacity of the olive-waste cake. Food Chem. 147, 170-176. https://doi.org/10.1016/j. foodchem.2013.09.121

Wickerham LJ. 1951. Taxonomy of yeasts. US Dept. of Agriculture.

Wilkowska A, Kregiel D, Guneser O, Karagul Yuceer Y. 2015. Growth and by-product profiles of Kluyveromyces marxianus cells immobilized in foamed alginate. Yeast 32, 217225. https://doi.org/10.1002/yea.3044 